\title{
The missing are not dead yet: Efraim Kamati Kapolo and the Impossibility of Disappearing Without a Trace
}

\author{
VILHO SHIGWEDHA \\ Department of Geography, History and Environmental Studies, University of Namibia
}

On 21 March 1990, Namibia gained its independence after 106 years of colonial occupation, first by Germany (from 1884 to 1918) and subsequently by South Africa (1920 to 1990). During colonial times, Namibians were victims of systematised racial and political oppression, as well as state-orchestrated acts of terror involving the racially motivated killing, deportation and disappearance of many people. In this article, I seek to examine the ongoing condition of ambiguity and inconclusiveness surrounding the 'presence and absence' of Namibians who went missing during the years of South Africa's repressive rule in Namibia, and especially during the apartheid period. Among the Namibian families I interviewed, missing persons are ever present, and many of the family members insist that those who went missing during apartheid are still alive despite decades of absence.

Against this backdrop, I present a case study from a collection of testimonies that reflect difficult, unresolved histories regarding Efraim Kamati Kapolo, who went missing following his arrest by members of the South African Defence Force (SADF) in September 1966, and who remains missing. ${ }^{1}$ Kapolo's disappearance was not an isolated event, and the testimonies resonate with painful experiences of many other Namibians who also went missing during colonial rule. My aim is to suggest a model for exploring the experience of losing loved ones, and for acknowledging the enormity of the pain and suffering that engulf the lives of many families who desire to know the truth about the fate of their missing loved ones and who have never received any acknowledgement or recognition from the state. I focus on the intricacies surrounding the perception that those who went missing were not dead. Perceptions are real and yet difficult to probe. While my conclusions are tentative, the rhetoric accompanying this case study may open up a debate which, in my understanding, is highly relevant to a society with the long-lasting trauma and suffering arising from the experience of colonialism, apartheid, war and terror. ${ }^{2}$

1 Following a ruling by the International Court of Justice in July 1966 in favour of South Africa's occupation and control of what was then South West Africa, now Namibia, the South West African People's Organisation (SWAPO) took up arms to fight for Namibia's independence. The first battle between SWAPO guerrillas and South African forces took place on 26 August 1966, and led to widespread arrests of suspected SWAPO fighters and supporters. National Archives of Namibia, 'Report on Meeting of the National Executive Committee, 2-9 November 1963', SA Treason Trials 67/68, Box 6.

2 See V. A. Shigwedha, 'The Homecoming of the Ovaherero and Nama Skulls: Overriding Politics and Injustices', Human Remains and Violence, 4, 2. 2018; L. Forster, D. Henrichsen and H. Stoecker, 'Tracing the Descendants of Kuiseb's 1884 Grave Robbery', The Namibian, 6 May 2016, 13. 


\section{State-sponsored violence in apartheid Namibia}

The dynamics of state-sponsored violence in Namibia started with Imperial Germany establishing and consolidating the political and economic autonomy of white settlers in the central and southern parts of Namibia. As is well known, Germany's policy of repression and the forced removal of Africans from their ancestral land culminated in the 1904-1908 genocide of the Herero and Nama people. ${ }^{3}$ After World War I, the interests that coalesced around South African rule also concentrated on central and southern Namibia for private land acquisition but increasingly and rapidly targeted northern Namibian communities as a vital region for cheap labour recruitment for the white farming community in central and southern Namibia. After World War II, the increasing imposition of apartheid led to the formation of the first African nationalist anti-colonial movements in Namibia, the South West African People's Organisation (SWAPO) and the South West African National Union (SWANU). SWAPO's subsequent launch of the Namibian armed liberation struggle in 1966 turned northern Namibia into a combat zone until 1989, with the South African Defence Force (SADF) attempting to eradicate the People's Liberation Army of Namibia (PLAN), SWAPO's military wing. The 23-year armed conflict escalated significantly after Angola achieved independence in 1975 under the MPLA. ${ }^{4}$ Subsequently, the MPLA, a strong supporter of SWAPO and the liberation of Namibia, invited SWAPO to establish military and civilian bases in southern Angola. ${ }^{5}$ This made it possible for PLAN combatants to regularly make contact with local communities in northern Namibia. It also resulted in an increase in violence, as South Africa strengthened the presence of its combat forces along Namibia's northern border with Angola. Given the intensity and longevity of the armed conflict, many families in northern Namibia were torn apart and uprooted from their homes and communities, and many individuals have remained unaccounted for following Namibia's independence from South Africa in $19900^{6}$

Interestingly, the SADF supported a number of locally established counterinsurgency units such as the South West Africa Territorial Force (SWATF), the South

3 For a general overview of Namibia in the late nineteenth and throughout the twentieth century, see, M. Wallace, $A$ History of Namibia From the Beginning to 1900 (Johannesburg: Jacana, 2011); H. Vedder, South West Africa in Early Times: Being the Story of South West Africa Up To the Date of Maharero's Death in 1890, C. G. Hall (ed. and trans.) (Oxford: Oxford University Press, 1938).

4 MPLA stands for Movimento Popular de Libertação de Angola; (People’s Movement for the Liberation of Angola).

5 See T. Sellstrom, Sweden and National Liberation in Southern Africa, Vol. 11: Solidarity and Assistance, 1970-1994 (Uppsala: Nordiska Afrikainstitutet, 2002), 350-351.

6 For studies of these issues from varied perspectives, see, for example, V. Shigwedha, The Aftermath of the Cassinga Massacre: Survivors, Deniers and Injustice, (Basel: Basler Afrika Bibliographien, 2017); A. Heywood, The Cassinga Event (Windhoek: National Archives of Namibia, 1994); P. Katjavivi, A History of Resistance in Namibia (London and Paris: James Currey and UNESCO Press, 1988); SWAPO, To be Born a Nation (London: Zed, 1981); J. Breytenbach, Eagle Strike: The Story of the Controversial Airborne Assault on Cassinga, 1978 (Johannesburg: Manie Grove Publishing, 2008), E. Alexander, 'The Cassinga Raid (MA thesis, University of South Africa, 2003); P. Stiff, The Covert War: Koevoet Operations, Namibia 1979-1989 (Johannesburg: Galago, 2004); W. Steenkamp, South Africa's Border War, 1966-1989 (Gilbraltar: Ashanti, 1989); E. N. Namhila, The Tears of Courage, Five Mothers, Five Stories, One Victory (Windhoek: Archives of the Anti-Colonial Resistance and Liberation Struggle, 2009); E. N. Namhila, Kaxumba kaNdola: Man and Myth, The Biography of a Barefoot Soldier (Basel: Basler Afrika Bibliographien, 2005); C. Williams, National Liberation in Postcolonial Southern Africa: A Historical Ethnography of SWAPO's Exile Camps, (New York: Cambridge University Press, 2015). 
West African Police and Koevoet (named after the Afrikaans word for crowbar), which carried out countless, 'wilful' killings of civilians, and were immune from prosecution for crimes that they committed. State-sponsored mass violence and tyranny against civilians in the war zone increased when the Internal Security Act was passed by the apartheid parliament as Act 74 of 1982. This formalised the repression of local populations, and empowered South Africa's so-called security forces and police to act with impunity against persons suspected of endangering the safety and security of the apartheid state. ${ }^{7}$ Principally, South Africa exported violence and war to Namibia, which it considered the frontline in its battle against communism and 'terrorism' during the Cold War.

The violence in northern and north central Namibias combat zones led to an exodus of tens of thousands of Namibians into neighbouring countries. SWAPO established numerous camp communities for exiles in Angola and Zambia. ${ }^{8}$ These upheavals and processes of social dislocation occurring amidst the complex dynamics of regional war and violence resulted in the loss of many lives and the disappearance of many people. In an effort to address and resolve the uncertainties experienced by many families with regard to those who did not return home after Namibia won its independence in 1990, SWAPO published a 320-page book, Their Blood Waters Our Freedom. This contained a list of names of people who went missing while in exile under SWAPO's care. ${ }^{9}$

In fact, the book was published in response to growing domestic pressure on SWAPO, especially following the publication of Siegfried Groth's book, Namibia: the Wall of Silence in $1995 .{ }^{10}$ Another source of pressure on SWAPO was repeated demands by an organisation (formed at the launch of Groth's book) calling for SWAPO to 'come clean' and disclose the names of those alleged to have been spies, who reportedly went missing under SWAPO's custody. ${ }^{11}$ To the disappointment of Namibians, who expected to find names of their missing loved ones and explanations as to what happened to their remains, SWAPO's book turned out to be the opposite. As Lauren Dobell notes, Their Blood Waters Our Freedom contained 7,792 names, with putative causes of death provided in all but 126 cases. SWAPO hailed the book as a positive development, and an important conciliatory gesture, despite its many serious omissions and discrepancies. Dobell further points out that some entries in the book contradict earlier testimonies concerning the demise of persons accused of being spies,

7 Inside South Africa, the state also cracked down on opposition to apartheid. As in Namibia, many South Africans were killed and disappeared at the hands of the South African security forces. However, with a population of around 20 million people in the 1980s, the impact of systematic mass violence and disappearances may have been more diffused than in Namibia, which had a tiny population of around a million people at the time, and where repression was arguably so prevalent as to be incomparable to the South African situation.

8 Shigwedha, Aftermath of Cassinga, 4; see also, M. Akawa, The Gender Politics of the Namibian Liberation Struggle (Basel: Basler Afrika Bibliographien, 2014); Williams, National Liberation.

9 SWAPO, Their Blood Waters our Freedom: Glory to the Heroes and Heroines of the Namibian Liberation Struggle (Windhoek, 1996).

10 See S. Groth, Namibia, the Wall of Silence: The Dark Days of the Liberation Struggle, H. Beyer (trans.). (Cape Town and Wuppertal: David Philip and Peter Hammer Verlag, 1995).

11 Breaking the Wall of Silence (BWS) is an NGO based in Windhoek, named after Groth's book Namibia, the Wall of Silence. The organisation was formed at the book launch in 1996. BWS advocates for the rights of those who claim to have been detained by SWAPO during the Namibian War of Independence. 
while the names of some former detainees who failed to return at independence were not included. ${ }^{12}$

Instances of mass violence committed by the SADF against Namibians, which involved the killing and uprooting of civilians, included the Cassinga and Osheetekela massacres of 1978, where more than a thousand Namibians were reported missing following an SADF attack on the two SWAPO camps in southern Angola. ${ }^{13}$ Other massacres include those in Oshikuku, Epinga and Oshatotwa, the bombing of Barclays Bank in Oshakati in 1988, as well as various instances of poisoning and dumping of captured PLAN fighters in the Atlantic Ocean. ${ }^{14}$ At the centre of these allegations stands Wouter Basson, alias 'Dr Death', a South African chemical-warfare expert who is accused of using chemical and biological warfare to eliminate apartheid dissidents in South Africa and Namibia. ${ }^{15}$ In addition, it is claimed that at the height of the war, from 1980 to 1989 , Koevoet alone claimed a killing rate of around 300 to 500 Namibians per year (for which its members were paid a bounty per corpse). ${ }^{16}$

Between 2000 and 2005 an oral history project (which I coordinated) initiated by the University of Namibia and funded by the Ford Foundation, collected personal testimonies from people living in the former war zone of north central Namibia. This culminated in the discovery of close to fifty unmarked graves of victims of the Namibian liberation struggle in this one region alone. Most of the victims were SWAPO combatants or their civilian supporters. Although the victims were secretly buried by local communities, in most cases, their names and places of origin were not recorded. The South African Security Forces regularly dumped the bodies of alleged SWAPO combatants in public places such as Cuca shops (shebeens), schools and church grounds. ${ }^{17}$ In many cases, local communities did not know the people whose bodies they found. Similarly, SWAPO guerrilla fighters targeted people they saw as

12 L. Dobell, 'Silence in Context: Truth and/or Reconciliation in Namibia', Journal of Southern African Studies, 23, 2, 1997, $371-382$.

13 For a detailed account of some cases of mass killings, torture and disappearance of Namibian civilians, see Shigwedha, Aftermath of Cassinga.

14 See J. Smith, 'Pursuing the Secrets of Dr Death', Saturday Star, 3 October, 2011. https://www.iol.co.za/saturday-star/pursuingthe-secrets-of-dr-death-1149537\(accessed 10 October, 2018).

15 These include Reverend Frank Chikane, whose poisoned clothes nearly killed him, and activist Siphiwo Mthimkulu, who was first poisoned with thallium before being abducted and murdered. Unforgettable reports presented to the TRC reveal Basson's alleged involvement in about 24 'death flights' in Namibia between 1979 and 1987. These involved prisoners - mostly SWAPO guerrillas - being loaded on to a plane, given drugs to paralyse them and then being tossed out of the aircraft thousands of feet above the Atlantic Ocean. See Smith, Saturday Star, 3 October, 2011.

16 See Truth and Reconciliation Commission of South Africa, 'The State outside South Africa Between 1960 and 1990' in Truth and Reconciliation Commission Report, Vol. 2, Ch. 2 (Juta: Cape Town: 1998), 75. Koevoet was a counter-insurgency unit set up in 1979 by Brigadier Hans Dreyer of the South African Police's security branch. Its combat units consisted mainly of black Namibians. In addition to Koevoet, SWATF was formed in the early 1980s to recruit Namibians into the army with the intention of indigenising the military conflict. Boys as young as 14 years old were targeted for recruitment to fight against SWAPO - and potentially their own brothers. This recruitment drive, combined with visits by the SA security forces to schools (sometimes to interrogate and beat up teachers and students), prompted many students to stay away from schools. Many young people, including myself, fled into exile and joined SWAPO, to avoid recruitment into the South African security forces and to complete our studies. See Stiff, The Covert War.

17 Some of this information is from interviews that I conducted in 2005 for the Archives of the Anti-Colonial Resistance and the Liberation Struggle. My work was sponsored by the National Archives of Namibia. Interviewees included: Festus Kaapanda KaNangolo, David Iilende, Shivute Sebulon, Selma Nangolo, Julia Nuulimba. Grave sites visited include: Okaalale (two missing people); Okakuyu (one missing person); Embumba (one missing person); Okathima kaNangolo (three separate graves, each with one missing person); Eyanda (one missing person); Okathitu kaKahala (one missing person); Otshuuli (one missing person); Olyasiiti\Iikokola (two missing people people); Omatha (one Oshihero-speaking missing person, locally known by their combat name, Kakoto); Ongulugumbe (mass grave containing 11 missing SWAPO combatants, known only by their combat names); Uulweege (two missing people); Okaku kaAmalwa (one missing person, known only by their combat name); Oshiku shOmunkente (one missing person); Ondukuta (one missing person); Ombugu (two missing Namibians) and many others. 
enemy collaborators, who were locally known as omapuli or eepaapeta. Many of these people were killed in much the same way. ${ }^{18}$

\section{Who is Efraim Kamati Kapolo?}

Efraim was born in 1919 as Kamati Kapolo at Olukuma village in Uukwaluudhi, north-western Owamboland. His father was Kapolo Keeshukuko and his mother was Shamba Amukwaya. They had eight biological children and Kamati was their third born. The narrative of Efraim's disappearance goes back to September 1966. This followed the first military confrontation at Ongulumbashe, in north-western Namibia, between the SADF and a handful of SWAPO guerrilla fighters. ${ }^{19}$ A year earlier, in March 1965, six SWAPO fighters had left Kongwa military training camp in Tanzania to conduct clandestine military training at centres in northern Namibia, and to prepare volunteers to confront South African forces militarily. ${ }^{20}$

When the Ongulumbashe recruitment and training camp was established in February 1966, Efraim and Isack Shoome both registered for training. In fact, Shoome and Kapolo were instrumental in suggesting Ongulumbashe as the most appropriate location in Western Owamboland for clandestine military training and political mobilisation. ${ }^{21}$ After completing three months of military training, Kapolo and Shoome were given responsibilities to solicit logistical support and food from local communities. In particular, Shoome was instrumental in passing on intelligence information to combatants as his homestead was very close to the Uukwaluudhi royal palace at Onalushwa village. The palace was not an independent political entity, especially after King Mwaala gwaNashilongo died, but it represented the Uukwaluudhi kingdom and traditional authority under the South African Bantustan-style administration of the Owambo ethnic group. For this reason, representatives of the South African government frequently came to brief the king, Josia Shikongo Taapopi on issues concerning South Africa's rule of South West Africa / Namibia. Shoome himself served as a counsellor in the Uukwaluudhi traditional authority.

\section{The Ongulumbashe attack, crackdown and disappearance}

The attack on SWAPO guerrillas at Ongulumbashe training camp was the SADF's first combat assault on a SWAPO military target. The attack was carried out just before

18 Omapuli (pl.) or epuli (s.) are Oshiwambo words that roughly translates as witch (omulodhi), or someone who is so morally corrupt that he or she deserves to die. The notion of omapuli seems to derive from the time of the Namibian liberation struggle and refers to those, mainly Namibians and a few South Africans, who were suspected of having been recruited to join SWAPO in exile to spy for apartheid South Africa. For more on this, see V. Shigwedha, 'Enduring Suffering: The Cassinga Massacre of Namibian Exiles in 1978 and the Conflict between Memory and Testimony', (PhD thesis, University of the Western Cape, 2012); Williams, National Liberation.

19 This is based on interviews I conducted in 2001 with Isack Shoome, Lameck Iithete and Kaapanda Kanangolo who were among the first people trained by six SWAPO combatants who infiltrated into north central Namibia from Tanzania in 1965.

20 For details about Kongwa training camp see, Williams, National Liberation, 65-93.

21 Given their knowledge of the area, derived from using it as a cattle post in the dry season, they identified the Ongulumbashe area as ideal for guerrilla activities because it contained a rich ground-water aquifer. In addition, local support for SWAPO was good, and included the clan of the popular and influential king of Uukwaluudhi, Mwaala gwaNashilongo until he died in 1960 (after ruling for 51 years from 1909). 
daybreak on 26 August 1966. A few days after the attack, a crackdown was conducted on escaping SWAPO guerrilla fighters and their supporters in north central Namibia. The arrest of SWAPO members and harassment of supporters became widespread throughout Owamboland. As Marion Wallace remarked,

By mid-1967 somewhere between 150 and 200 people had been arrested in Namibia and detained and tortured in South Africa. They included PLAN fighters and most of SWAPO's internal leadership .... Detainees' relatives in the north also faced severe hardships. ${ }^{22}$

A short period of relative calm occurred in Namibia after the assassination of South Africa's Prime Minister Hendrik Verwoerd in Cape Town on 6 September 1966 (just two weeks after the Ongulumbashe attack) but tensions flared again after Verwoerd's funeral on 10 September. Confidential SWAPO documents found in the Ongulumbashe camp gave the South Africans access to the names of trainees and information about those who had supported the combatants with ammunition, food, clothes and money. By the end of September 1966, most of these people had been detained and sent to South Africa. In 1967 and 1968, 37 Namibians were tried for 'terrorism' in Pretoria under the newly created Terrorism Act of 1967.

While Shoome and a few of his comrades evaded arrest by staying on the run for months and even years, Kapolo decided not to go in hiding. ${ }^{23} \mathrm{~A}$ few days after the Ongulumbashe battle, the SADF detained him at his home in Elondo, $40 \mathrm{~km}$ east of Ongulumbashe. He was first taken to Tsandi where he was paraded and shamed in front of a public that had been invited to hear him confess to the crimes that he and others were alleged to have committed against the apartheid state and local chiefs. Tsandi was the most developed settlement in the Uukwaluudhi area and also where the South African administrative centre was located. Here, with the support and respect of local communities, some Finnish missionaries also ran a mission station, a clinic, and a boarding school for girls, locally referred to as Okagumbo.

Kapolo's wife, Magdaleena Nelago Mutota, was visiting the clinic with a sick child on the day of her husband's arrest and public shaming. She was among those who witnessed his detention, torture and interrogation by the SADF. According to their daughter, Aune Nekwaya Kapolo, Magdaleena had to endure the shock of seeing her husband so badly beaten that he was unable to walk. His nose was bloodied, his face swollen, and his eyes were saturated with tears. ${ }^{24}$ Aune was a student at the Finnish boarding school at Tsandi, so she, too, witnessed her father's detention and torture.

22 See, “Torture” Case Settled', Agence France Presse, 2 November 1968; 'Africans Allege Assault', Times, 17 October, 1967, 2; Namhila, Kaxumba kaNdola, esp. 59-79; and Namhila, Tears of Courage.

23 According to people I interviewed who knew Kapolo, including Isack Shoome, Festus Kaapanda kaNangolo, Aune Kapolo, Junias Vaino Kaapanda, among others, he was very stubborn, with some even describing him as 'a blockhead'.

24 Interview with Aune Nekwaya Kapolo at Elondo in Uukwaluudhi, Nambia on 20 January, 2018. About the torture of other Namibian political detainees (especially Kaxumba kaNdola) by South African security forces, see Namhila, Kaxumba kaNdola, esp. 99. 
She remembers it this way:

My father was in pain but resolute. He told my mother that he was in the hands of the enemy and with little prospect to return home soon. He asked her to take care of us [the children] and our homestead. Minutes later, they tossed him into a police van. We never saw him again. No one told us where they took him, and what happened to him thereafter remains a mystery. ${ }^{25}$

The family were never able to ascertain whether Kapolo received any treatment for the serious injuries he sustained from beatings and floggings on the day of his arrest. Until today, this state of not knowing what happened to Kapolo beyond the point at which he was paraded before the public continues to haunt his family, generating the irreversible and intense pain and suffering of uncertainty.

However, according to other Namibian detainees who were taken to South Africa but later released and returned to Namibia, Kapolo was with them in Pretoria. They make no mention of the injuries that Kapolo sustained when he was arrested, but report that 'beatings and kickings' were routine during interrogation in Pretoria. As a result, some inmates, including Johannes Shimweefeleni, James Hamukwaya and Kapolo were reportedly 'beaten so badly on the head that blood, and later on pus, was coming out of their ears. It was frightening to look at them. ${ }^{26}$ It is further alleged that these three inmates (Kapolo, Shimweefeleni and Hamukwaya) succumbed to their injuries as a result of brutal torture and inadequate medical care while in prison. ${ }^{27}$ In view of the sources I have consulted and examined, it is apparent that former Namibian detainees in Pretoria are generally of the view that comrades who did not return to their families in Namibia after their imprisonment in South Africa belong to the category of political prisoners who went missing during the apartheid era. The complexity of classifying missing prison inmates as dead lies in the fact that not one of their fellow prisoners witnessed the death or burial of these three men.

\section{The impossibility of disappearing}

In her book, Missing People and Politics, Jenny Edkins argues that 'when a person goes missing, what's happened doesn't seem possible: people don't just disappear'. More importantly, 'people cannot be allowed to just disappear. ${ }^{28}$ Commenting on the impossibility of disappearing without a trace, Kapolo's only surviving daughter remembers her mother, Magdaleena, saying the following shortly before she died in 2012:

\footnotetext{
Interview with Aune Nekwaya Kapolo, 20 January 2018.

Namhila, Kaxumba kaNdola, 103.

See, National Archives of Namibia, 37 Guerrilla Trial, September-December 1967, A570, 4/5.

J. Edkins, Missing People and Politics (Ithaca, NY: Cornell University Press, 2011), 1, 4.
} 
If someone out there can just let me know what actually happened to my husband, I will die peacefully. ${ }^{29}$

These words suggest that Magdaleena's battle to know the truth of what happened to her missing husband intensified when she learned that she had a terminal illness and had only a few months left to live. Aune described how at the end, her mother became obsessed with victimhood which, according to Aune, disempowered her and made her more vulnerable to her illness. This was due to a combination of different factors, especially the 'pact of silence' that has surrounded the disappearance of her husband for so many decades. Aune described the decades-old pact of silence as tantamount to exacerbating the pain and suffering of the affected families. This is due to legislation in both Namibia and South Africa that empowers the former oppressors to remain silent about crimes committed under apartheid and colonialism as disclosure might not be in the best interests of the perpetrators or their associates.

Nevertheless, I succeeded in obtaining some of Kapolo's medical records from the time he spent in prison in Pretoria in 1967. In addition, recent reports of the discovery of his burial site at Rebecca Street Cemetery in Pretoria West, appear to show that he is actually dead. According to state records and the cemetery register, obtained from Madeleine Fullard who leads South Africa's Missing Persons' Task Team, Kapolo was buried at the Rebecca Street Cemetery by the firm of undertakers, WH Rogers, on 8 November 1967. His grave is number G3785. It seems he is the only person buried in this grave. His name is misspelled in the cemetery register as Efraim Komati Kaphoro, and his date of death is listed as 12 October 1967. This date contradicts reports provided by H. F. Verwoerd Hospital in Pretoria which give Kapolo's date of death as 6 October $1967 . .^{30}$

According to Fullard, the hospital recorded Kapolo's (also spelled Kaphoro) cause of death as 'Emphalis Meyelitis'. This may translate into a disease called transverse myelitis, a neurological condition in which the spinal cord becomes inflamed. A more comprehensive account of Kapolo's battle with poor health, inadequate medical treatment and subsequent death is apparent in his prison medical records, which have been deposited in the National Archives of Namibia. A summary of Kapolo's treatment while awaiting trial in prison indicates that Accused No. 33, Efraim Kamati Kapolo, complained of unspecified pain and aches for which he received pain tablets and penicillin injections on 3 July 1967. A few days later, on 7 July 1967, he received aspirin tablets for a toothache. On 18 September 1967, he was booked into the prison hospital to have the bad tooth removed. Following this, Kapolo is reported to have suffered severe headaches, as well as a swollen face and head. Between 21 and 25 September, he received headache pills, aspirin tablets and penicillin injections for pyorrhoea. On 26 September 1967, Kapolo visited the prison hospital, after his health deteriorated again, where he was referred to a Dr Combrink. On 28 September 1967,

29 Interview with Aune Nekwaya Kapolo, 20 January 2018.

30 Fullard became interested in Kapolo's story in response to the paper I presented at the 'Missing and Missed' workshop, University of the Western Cape, 2018. 
he was finally transferred to the H. F. Verwoerd Hospital where he was attended to by a Dr Neuberger but died on 6 October 1967. ${ }^{31}$

In May 1984, Gaus Shikomba was released from the Robben Island prison after spending nearly 15 years in jail. Upon his return to northern Namibia, he visited Kapolo's family and relatives to inform them of Ephraim Kapolo's death. Shikomba presented the family with clothes and shoes that had been in Kapolos possession, even though he had then been missing for nearly 18 years. Presenting the deceased's eemwiya (belongings, such as clothes and shoes) to a bereaved family is customarily (among the Oshiwambo speaking people) a way of showing the next of kin that death is corporeally evident when circumstances beyond one's control prevent the return of the deceased's body to his or her family.

Nevertheless, the clothes that Shikomba presented to Kapolo's wife did not persuade her that her husband was unmistakably dead. For her, the return of some of Kapolo's belongings provided no evidence that death had actually taken place, just as Kapolo's prolonged absence from his family did not necessarily prove him dead. Intriguingly, Shikomba was Efraim Kapolo's confidante and a long-time family friend. Magdaleena, in particular, had known him since the early 1960s, as a young SWAPO activist who had visited her husband at their homestead, along with many other youths from all over Owamboland, to attend secret political meetings that preceded the Ongulumbashe attack. Yet, Magdaleena still needed solid evidence to justify the belief that her husband was actually dead.

The same can be said of dissociation from state documents, such as archival records. Such official records can make death seem invisible, abstract and unrealistic when they are questioned by the relatives of missing people. For example, Aune Kapolo asked puzzling questions when I showed her some of the documents I retrieved from the National Archives of Namibia, including a certificate stating that her father had died in a Pretoria hospital on 12 October 1967. If he is dead, she wanted to know, what happened to his body? Who buried him? Where did they bury him? When did they bury him? Why did they bury him as if he had no family to bury him or to accept that he was dead?

For Aune, rather than providing any satisfactory answers, the archival records, both fragmented and abstract, invited further questions. This intriguing perspective warrants a brief exploration. Aune's response may suggest the inadequacy of archival testimony to articulate and make death visible as it claims to do. Put differently, when death takes place in the absence of seeing, 'it may cause the dead to lose some of their particularity. ${ }^{32}$ This seems to be what caused Aune to question whether the alleged death of her missing father really occurred. Moreover, her and her mother's

31 Kapolo's medical records are written in Afrikaans and read as follows: Beskuldigde No. 33 Ephraim Kamati Kapolo opgeneem 24 9. 66: 3.7.67. Asefen tablette, pynpille en penicillen inspuitings; 7.7.67. Slegte tand. Tabs. A.P. Cods 2-3 maal per dag; 18. 9. 67. Tandpyn - reel vir trek op 19.9.67; 21. 9. 67. Kopseer - pynpille; 25. 9. 67. Pyrrhoea-penicillin inspuitings en aspirin tablette; 26. 9. 67. Opgeneem in gevangenishospitaal. Verwys na Dr. Combrink (Intrnis); 28. 9. 67. Oorgeplaas na H.F. Verwoerd hospitaal onder behandelling Dr. Neuberger; 6. 10. 67. Oorlede. National Archives of Namibia, SA Treason Trials 67/68, Box 4, A570: S4/5.

32 L. Renshaw, 'Missing Bodies Near-at-Hand: The Dissonant Memory and Dormant Graves of the Spanish Civil War' in M. Bille, F. Hastrup, T. F. Soerensen, (eds), Anthropology of Absence: Materialization of Transcendence and Loss, (Berlin: Springer, 2010 ), 49. 
search for Kapolo was not about finding him dead as per the testimony of the archival documents. It is a search for a person, not for a body, evidence of a burial site, or for any way of 'bringing relief' to the 'deceased's' family.

Certainly, it is evident that regardless of the fragments of archival testimony that suggest that Kapolo is dead, his family remains vulnerable to the distress of his symbolic presence. This induced the fixed memory of seeing him alive, endless nightmares about his possible suffering, and the fallacy of being reunited with him again. This complex and sophisticated ambivalent thinking in the Kapolo family transcends perceptions that archival documents constitute indisputable records of evidence. While archival documents should be embraced as disclosing official evidence that Kapolo is dead, they continue to unsettle lives of his family and the families of other missing people.

Similarly, claims of Kapolo's death were also made in October 1967, when some South African officials paid a visit to Keeshukuko's homestead with the news of his son's death. Strangely, the officials did not disclose any information about the cause of his death, nor did they indicate where his body was. ${ }^{33}$ Then, to try to persuade the family that Kapolo was actually dead, the South African messengers visited Keeshukuko again shortly afterwards, to ask him whether he was interested in the return of his son's remains from South Africa. Absurdly, Keeshukuko was asked to pay for the cost of transporting his son's body from Pretoria to Ondangwa airport in northern Namibia. From there the remains would be transported by road to the deceased's homestead, $120 \mathrm{~km}$ west of Ondangwa. This time Keeshukuko did not mince his words:

Over my dead body. My son is not dead yet and I expect nothing but to see him back home alive and well. ${ }^{34}$

This scene added another layer of anger and pain, reinvigorating family frustration over the years as the South Africans presented them with no evidence to corroborate their claims that Kapolo was dead. It also put the South Africans on the spot in terms of their accountability for Kapolo's disappearance. In light of medical ethics, and the principle of human dignity or consideration for the worth of others, both the Verwoerd and Pretoria Central Prison hospitals could have informed Kapolo's family about four important things. First, they could have informed the family about Kapolo's illness and deteriorating health in prison. Secondly, they could have notified them of Kapolo's death. Thirdly, they could have made arrangements to return the deceased body to the family. Fourthly, they could have given the family information about the burial arrangements and the location of his grave in Pretoria. Alas, none of these options was given any consideration by the repressive, carceral or medical 
branches of the apartheid state. Even more painfully, Kapolo's 'dead body' was treated as that of an 'unmissed person, ${ }^{35}$ someone with no family ties, no relations, and no one who cared about his death, no one to honour him with a fitting burial and appropriate death rituals, no one who might need 'corporeal certainty' of his fate.

Of course, rumours of Kapolo's 'death' spread like wildfire after the visit of the South African emissaries. However, given the prevalence of political intimidation at the time, many people in the community stayed away from Kapolo's family and avoided being seen visiting the 'deceased's house' or onghanda. This meant that Kapolo's community was forced to violate their own customary practices and death rites as they feared for their own lives and for the safety of their families.

\section{Disappearance, rumours and customary practice}

For reasons best known to themselves, the South Africans made no further contact with the family following their altercation with Kapolo's father, resulting in an extended silence on this matter until Namibia won its independence in 1990. The fact that the South African government did not see itself as responsible for repatriating Kapolo's 'remains' to his family, or even communicating with them about where he was buried, shows the apartheid state's utter lack of consideration for the suffering of black people. This gave rise to poor communication about life and death in respect of apartheid detainees, and this was why their families were kept in the dark. ${ }^{36}$

More importantly, these cases suggest that the perpetrators of apartheid were and remain unaccountable for untold atrocities, unanswered difficult questions and scars of apartheid's brutal history that continue to haunt and hurt many Namibians. Indeed, this also shows why perpetrators of apartheid atrocities against Namibians who opposed apartheid and racial segregation have remained untouchable, fully protected by constitutional law in post-apartheid Namibia and South Africa. In particular, this anomaly makes reference to the skewed policy of national reconciliation in postcolonial Namibia and the failed Truth and Reconciliation Commission in post-apartheid South Africa. As fate would have it, Kapolo's father died of old age (his exact age unknown), still convinced that his son was not dead. This belief was an expression of a politics of uncertainty and ambivalence, which sought to challenge the apartheid authorities' administrative disdain as much as their inadequate archival traces.

Of course, Kapolo's family was keen to visit Pretoria to uncover the truth and search for missing details surrounding the rumours about their missing loved one. Yet, considering the fact that many black Namibians lived below the poverty line

35 As is evident from similar scenarios across the globe, and as per the UN Convention of 1956, those who die in political conflict are liable to be located, uncovered and returned in various forms, and within unspecified timeframes, to their relatives and communities. The inherent instability of a missing or clandestinely buried body lies in the potential for the living to effect some change in the status of the dead through exhumation. The absent dead can therefore remain a site of unresolved emotion and ongoing political tensions that can outlive even generations of mourners. This potentiality and tension can be activated after decades of apparent dormancy. See, for example, Renshaw, 'Missing Bodies', 48.

36 For a detailed account of the lack of communication between Namibians detained and imprisoned in South Africa and their families back home, see Namhila, Kaxumba kaNdola, 102-133. 
and were financially unstable under apartheid rule, it was almost unthinkable that Kapolo's family would be able to afford to travel to South Africa and back, let alone cover the cost of repatriating a dead body to Namibia. No one in the family had work or any stable source of income when the news of Kapolo's death reached the family and the community. This is not to ignore the fact that many communities in northern Namibia were self-sufficient in terms of food production, despite economic hardships, as they engaged in seasonal subsistence farming. While not everyone in the community owned livestock, cattle and goats were also a source of livelihood for many. However, livestock and their by-products could not be sold commercially, as was (and still is) the case for privileged white farmers, north of the so-called red line. ${ }^{37}$ Politically, it was also challenging for friends and sympathisers to help the family with the money needed to return the 'remains of an insurgent' (to use the language of the oppressor) to his birthplace. As mentioned earlier, it was even difficult for friends and community members to openly visit the grieving family to show their solidarity.

Customarily, the death of a husband (the crux who holds the family together) is perceived as marking the moment when the deceased's family (widow and children) begins to fall apart and disintegrate. Conventionally, the widow and children could be subjected to crude customary practices and exploitation by the family and clan of her late husband..$^{38}$ For instance, the widow would be obliged to remarry immediately, preferably to a brother of her late husband, regardless of whether or not he was already married. Likewise, the deceased's children could also be subjected to abuse and separation from their mother. This would not only subject the children to separation anxiety and insecurity, but also disrupt sibling relationships and bonds. In the same way, the deceased's property was usually inherited by his birth family, thus excluding his widow and biological children, and the deceased's children could be claimed by the same relatives. Adding to this trauma, the wife and children could be ordered to vacate the deceased's homestead, forsaking any farm land and domestic animals. Thus, the widow and children were customarily considered unrelated to the deceased, and could be left with nothing to inherit.

In a very unusual move, despite the rumours of Kapolo's death, Magdaleena and her six children were not ordered out of the family homestead and nothing was taken from them. Nor was Magdaleena compelled by her husband's family to find a new husband as tradition would usually dictate. This breach of Oshiwambo tradition can

The red line, also referred to as the veterinary cordon fence, is a pest-exclusion fence separating northern Namibia from the central and southern parts of the country. South of the fence, commercial farmers many of whom are white, can own land, and most of the farms are fenced in and accessible by reasonably well-maintained farm roads. North of the line, on the other hand, all farm land is communal and cultivated by mostly black farmers. Livestock raised north of the Red Line, and meat products from them, may not be exported, whereas farmers south of the line are free to sell their meat anywhere. Since independence, the government has struggled to remove the Red Line to enhance prosperity in the northern regions.

38 For details on women and inheritance customs in Namibia, see, for example, O. C. Ruppel (ed.), Women and Customs in Namibia: Cultural Practice Versus Gender Equality? (Windhoek: Konrad Adenauer Stiftung, 2008); R. Gordon. (ed.), The Meaning of Inheritance: Perspectives on Namibian Inheritance Practices (Windhoek: Legal Assistance Centre, 2005); M. O. Hinz, 'Law Reform from Within: Improving the Legal Status of Women in Northern Namibia', Journal of Legal Pluralism and Unofficial Law, 39, 1997, 69-79; D. LeBeau, E. Iipinge and M. Conteh, Women's Property and Inheritance Rights in Namibia (Windhoek: University of Namibia and Pollination Publishers, 2004); M. Ovis, Customary Laws and Inheritance in Namibia: Issues and Questions in Developing New Legislation (Windhoek: Legal Assistance Centre, 2005). 
be explained by a number of dynamics. Firstly, the landscape of political violence succeeded in disrupting local traditions, breeding fears and insecurity within families and clans. Secondly, Magdaleena was one of only a few women who were active in providing the SWAPO fighters with food and accommodation when they visited her husband for clandestine political meetings. ${ }^{39}$ In particular, after the Ongulumabashe training camp was set up, Magdaleena was among those who ensured that combatants in the bush received a monthly supply of flour, so that they could make oshithima (a kind of porridge), a staple food in northern Namibia. ${ }^{40}$ To do this, Magdaleena had to make the flour by pounding omahangu (finger millet), and her role in this regard earned her the respect of many in her husband's family and the community at large. This probably discouraged her husband's family from treating her disrespectfully following the rumours of Kapolo's death. To do so might also have invited political repercussions or revenge from SWAPO combatants. Thirdly, the failure to exercise customary practices against Magdaleena and her children points to the complexity and politics of uncertainty surrounding Kapolo's fate. The rumours about Kapolo's death were perceived as incoherent and left many in the community in a state of disbelief and ambivalence.

Along the same lines, it is also interesting to note that when the head of a household dies, the family traditionally destroys the deceased's homestead and relocates to a new one that they built some meters away. This change of place is believed to disorient death, and to prevent it from returning to the same homestead to take another life. Contrary to this tradition, Kapolo's wife and children remained in the same homestead as if Kapolo was merely physically away from home for a given period. In addition, no major changes were made to key external structures within the homestead - Kapolo's bedroom was maintained and remains so to this day. Yet, as the decades wore on, each year seems to have been more harrowing for Magdaleena and her children. Aune remembers her mother as follows:

She couldn't stop grieving. As a result, she often experienced general weakness of the body to the extent that she became so powerless to do anything for several days or even weeks. Sometimes she resorted to singing hymn songs, which we interpreted as a way of confiding her ongoing suffering as a result of unsubstantiated rumours surrounding the disappearance of her husband. ${ }^{41}$

As Verena Tschudin observes, grief is a complicated emotion that can surface as sadness, shock, anger, confusion, apathy, and guilt. ${ }^{42}$ Certainly, nothing could

39 For a detailed account about some of the other women who were active in the Namibian liberation struggle, see Namhila, Mukwahepo, Woman, Soldier, Mother: As told to Ellen Ndeshi Namhila (Windhoek: UNAM Press, 2013); Namhila, Kaxumba kaNdola, esp. 59-79; Tears of Courage; and Akawa, Gender Politics.

40 According to information provided by Aune Kapolo, her mother, Magdalena, received recognition as a veteran of the Namibian liberation struggle following Namibia's independence and was given a monthly income of $\mathrm{N} \$ 2,200$ from the Namibian government.

41 Interview with Aune Nekwaya Kapolo, 20 January 2018.

42 V. Tschudin, Counselling for Loss and Bereavement (Philadelphia, PA: Bailliere Tindall, 1999), cited in G. Betz and J. M. Thorngren, 'Ambiguous Loss and the Family Grieving Process', The Family Journal, 14, 4, October 2006, 359 - 365, at 259. 
have taken away the grief and uncertainty regarding her husband's fate, other than knowing whether he was dead or alive. According to Aune, her mother never gave up the hope that she would not die before finding answers to what actually happened to her husband, including locating his remains and conducting a proper burial for him if she found out that he had actually died.

The notion that she would not die without finding out about the fate of her husband might be linked to developments following Namibia's independence in 1990. In particular, her expectation of finally getting to the bottom of the circumstances surrounding Kapolo's disappearance was ignited by a number of meetings she had with officials from the National Museum of Namibia. ${ }^{43}$ At the time, she thought the purpose of the interviews was to facilitate the return of his husband, or his remains if he was indeed dead. She had high hopes that justice would finally be done after so many decades of uncertainty, loneliness and suffering. She even requested the involvement of the SWAPO leadership to assist in efforts to find her husband. But as she grew older, she was no longer interested in the interviews, nor could she remember everything about the disappearance of her husband. Towards the end, she could not even remember her husband's name. As Aune remembers, 'she always called me whenever she received visitors who came to interview her. Toward the end of her life, she was really heartbroken and tired of interviews which produced no tangible results.' Aune also remembers her mother telling a team of interviewers: 'I fail to understand the purpose of your interviews. You had been here many times to interview me with no end result to ease my pain, suffering and sorrow. ${ }^{34}$

Nevertheless, as indicated, the ambiguities surrounding the disappearance of Kapolo resonates with experiences and testimonies regarding many other missing people, not only in Namibia but across the region. In Namibia, men were particularly targeted by the South African security forces. As a result, most of the people who went missing during the war of independence in Namibia were male. Certainly, many of the women whose husbands went missing became double victims: victimised as a result of the uncertainty surrounding the absence and disappearance of their husbands, and then also by the challenge of acting as the heads of households, as single parents and as providers for the needs of their children.

Following the arrest of her husband in 1967, Priskila Tuhandeleni spoke of her experiences as follows: 'I struggled under very difficult circumstances without really much support to feed, clothe, and provide shelter and security to my children after the Omugulu gwombahe [Ongulumbashe] attack ... As for my husband, I only heard rumours that he had been arrested, and not a word about where he was jailed and whether he was alive. Although this anxiety lasted mainly for seven years, these were extremely long and lonely seven years. ${ }^{35}$ with Magdaleena Mutota.

44 Interview with Aune Nekwaya Kapolo, 20 January 2018

45 Priskila Tuhandeleni was the wife of Kaxumba kaNdola - one of apartheid South Africa's 'most wanted terrorists' following the Ongulumbashe attack and Accused No. 1 in the indictment of the 37 Namibians who were tried in Pretoria under the Terrorism Act, No. 83 of 1967. kaNdola was imprisoned on Robben Island in February 1968. Namhila, Kaxumba kaNdola, 75 
Sadly, although women whose husbands went missing needed counselling and assistance in different ways, and from different groups and individuals, they often found themselves isolated because people feared political reprisals. Nevertheless, in a few cases 'some community members helped' by donating food and utensils, but they did this 'discretely, usually in the evening', when no one could see them visiting the homes of these women. ${ }^{46}$ In some ways, resorting to sharing their experiences by talking to each other became a regular practice adopted by these women as they learned to cope with their fears and isolation, especially when they reached advanced age. As Aune put it:

In their late seventies and early eighties, barely a week passed without my mother paying a visit to gwaKamholo (Petrus Niilenge's wife) or gwaKamholo visiting my mother at our house. They often talked about their husbands and expressed hope that with the new political dispensation following Namibia's independence, the uncertainties surrounding their husbands' disappearance will be finally resolved. ${ }^{47}$

Additionally, the renewed hope that many families would find answers to what happened to their missing loved ones was ignited by two important developments in Namibia after independence. Firstly, demands for the repatriation from Germany of the remains of OvaHerero and Nama people intensified, and negotiations began regarding reparations for the 1904-1908 genocide against these two communities. ${ }^{48}$ Secondly, demands for the repatriation of the remains of Namibian liberation-struggle icons' from Angola and Zambia, ${ }^{49}$ were coupled with calls for the return of the remains of thousands of missing Namibians who were buried in Angola, Zambia and other countries that hosted Namibians during the struggle for independence. According to Aune Kapolo:

There was a time when my mother and GwaKamhola were particularly demanding to see the government involved in helping them find answers about what happened to their husbands. At one time, they convened a meeting with us, Kapolo and Niilenge children. They asked us to write a letter on their behalf, about their grievances for the attention of the Namibian government. I drafted the letter which I personally handed to Comrade Hifikepunye Pohamba when he visited our constituency, Onakaheke. We waited and waited for a response but it never came. ${ }^{50}$ 
In fact, the letter that the two families addressed to the Namibian government does appear to have shaken things up to some extent. Following its submission, speculation emerged that the grave of Festus Nehale, a former Robben Island prisoner, was found at the Maitland Cemetery in Cape Town. In the following years, Betty Hango-Rummukainen and a few other staff from the National Museum of Namibia visited Cape Town to conduct some research into missing Namibian political prisoners who were suspected of having died in South African prisons. The visit to Cape Town was sponsored by the American Embassy in Windhoek and according to Hango-Rummukainen's report, Festus Nehale died on 4 March 1971 and was buried on 8 March of the same year. His grave is at Plot No: 52457 B, is marked No. 2, and is easily accessible from Gate 6 of Maitland Cemetery. The same report also confirmed the location of the grave of Petrus Simon Niilenge (gwaKamholo's husband), who hailed from Kapolo's village and who had been incarcerated on Robben Island. According to Hango-Rummukainen's report, Niilenge died on 13 March 1974 and was buried on 19 April of the same year at Nyanga Cemetery in Cape Town. His grave bears the number CA10208. ${ }^{51}$

Following these discoveries, it was rumoured that the Namibian government was preparing to repatriate the remains of these former political prisoners. However, this is yet to materialise. Citing shortage of funds, Hango-Rummukainen and her team reported that they could not travel to other cemeteries around South Africa, particularly in Pretoria, to search for more graves, but they did report that 'two comrades passed away while awaiting trial in Pretoria and are suspected to have been buried there. ${ }^{52}$ The 'two comrades' were Efraim Kapolo and James Hamukwaya, alias Hangula Shoonyeka. According to Hango-Rummukainen, Shoonyeka was wounded in the attack on Ongulumbashe, and then captured and taken to Pretoria. He was murdered in April 1967 during police interrogations conducted at the Compol Building in Pretoria. His body was found by a warder the following day, but he was reported as having committed suicide. What happened to his body after this, remains a mystery to this day. ${ }^{53}$

Regrettably, even though these disclosures date back to 2002, when HangoRummukainen and her team visited Cape Town and reported on the findings, no follow-up has occurred since. As Geoffrey Glassock has suggested, 'it appears that disappearances are a discounted statistic, seemingly not newsworthy and irrelevant to the political agenda of a nation. ${ }^{54}$ Magdaleena has since passed away and at the time of writing, Niilenge's widow has reached an advanced age, is physically frail, and in and out of hospital. Nevertheless, the rest of the family members of these two missing persons remain hopeful that a day will come when they will know the truth

51 B. Hango-Rummukainen, in 'Footprints of Namibian Political Prisoners on Robben Island: Budget and Receipts, 2000-2003', an unpublished report submitted to the National Museum of Namibia. (Hango-Rummukainen's handwritten report is less than a page long.)

52 H. Shityuwete, In 'Footprints of Namibian Political Prisoners on Robben Island: Budget and Receipts, 2000-2003', National Museum of Namibia, 1 (This part of the report consists of two half pages)

53 Hango-Rummukainen, 'Footprints'.

54 G. Glassock, 'Coping with Uncertainty: The Grieving Experience of Families of Missing People', Bereavement Care, 25, 3, 2006, 43-46. 
about the fate of their missing loved ones. Certainly, besides the Kapolo and Niilenge families, many other families in Namibia whose loved ones went missing under unexplained circumstances during the liberation struggle, also demand answers and the resources of justice to help them to come to terms with what happened to their missing loved ones.

This points fingers at the political leadership in Namibia which has failed to address the plight of families of the missing people in a timely and sympathetic fashion. In particular, these missing persons could have been acknowledged as heroes and heroines of the Namibian liberation struggle, and yet they have not received appropriate government recognition for their political work. This process of recognition and acknowledgement should have started right after independence. Sadly, many of those who lived to see the end of the independence struggle were left to live in abject poverty coupled with endless frustration - a plight that often brings about untimely death - and many have since died without receiving any recognition from the state. In fact, some were already pensioners when Namibia won its independence, but still they received no recognition or support as veterans of the Namibian liberation struggle.

According to Aune Kapolo, Tate Benjamin, Joseph Uushona, Shinima Niilenge, and Julius 'Kashuku' Shilongo all died in poverty. Ironically, the Namibian government built a house for Uushona posthumously. Although he was given a few cattle some years before he died, he derived no benefit from them as they were all killed as a result of drought. ${ }^{55}$

This lack of recognition by the current Namibian government has contributed to the ongoing sense that many Namibian liberation fighters, as soldiers and as persons, are still missing.

\section{Conclusion}

In this article, I have tried to explore the contradictions and ambiguity surrounding missing people: the impossibility of affected families accepting the invisibility of death and their insistence on the possibility that their missing relatives are still alive somewhere, even when shown documentary traces of their death. Drawing from the Kapolo family's narratives of missing their husband and father for many decades, I have attempted to create an engaged discussion, to try to reveal the dilemma, suffering and endless pain of affected families. By exploring their emotional suffering, I sought to untie the ongoing state of ambiguity about the presence and absence of missing loved ones. I argue that although Kapolo has not been physically present in the family for a prolonged period of time, for them he is still very much alive. He remains a presence in family social and psychological interaction, and he remains socially and psychologically connected to his family wherever he is - dead or alive. 
Missing a family member under unexplained circumstances, is an unacceptable dilemma that no family would wish to experience and live with. Missingness can result from natural, political or human causes, but the grief and pain that arise in response to such missingness attach no category to how the person went missing; 'missing is missing' and the suffering that arises is the same. Nevertheless, while acknowledging their incompleteness and lack of full credibility for Kapolo's family, the archival documents consulted for this study may provide readers with important residues or fragments that when pierced together might reveal some useful and leading facts about Kapolo's fate. Moreover, considering the developments and speculations about the discovery of Kapolo's grave in Pretoria, it is hoped that his remains may one day be exhumed and repatriated for reburial by his family. Even so, it remains debatable whether such a step would enable his family to heal, and find justice. In remaining missing, Kapolo might indeed, in many ways, remain alive. 